\title{
PENGEMBANGAN MODEL KURIKULUM PENDIDIKAN ANAK USIA \\ DINI BERBASIS DEVELOPMENTALLY APPROPIATE PRACTICE \\ UNTUK MENUMBUHKEMBANGKAN KECERDASAN INTERPERSONAL DAN KECERDASAN INTRAPERSONAL
}

\author{
Nenden Ineu. $\mathrm{H}$ \\ (Dosen UPI Kampus Cibiru)
}

\begin{abstract}
ABSTRAK
Penelitian ini berlandaskan pada anak usia dini, yang merupakan masa keemasan yang mana masa ini masa peluang segenap potensi akan tumbuh dan berkembang secara optimal jika difasilitasi sesuai kebutuhan dan keberadaannya.Juga merealisasikan Undang-Undang RI no 20 tahun 2003 tentang Sisdiknas pasal 1 butir 14 bahwa Pendidikan Anak Usia Dini adalah suatu upaya pembinaan yang ditujukan kepada anak sejak lahir samapai usia 6 tahun yang dilakukan melalui pemberian rangsangan pendidikan untuk membantu pertumbuhan dan perkembangan jasmani dan rohani agar anak memiliki kesiapan dalam memasuki pendidikan lebih lanjut. Olehkarena itu, anak usia dini dikembangkan secara kreatif melalui pengembangan kurikulum berbasis DAP(Develepmentally Appropiate Practice). Kurikulum berbasis DAP adalah sebuah pendekatan dalam pendidikan yang didasarkan hasil penelitian tetang bagaimana anak-anak berkembang dan belajar, dan apa yang diketahui tentang pendidikan anak usia dini secara efektif. Metode penelitiannya menggunakan metode Delphi melibatkan ahli PAUD. Dengan teknik pengumpul data dan analisis data menggunakan angket, wawancara, studi dokumentasi, eksperimen dan observasi, kemudian dianalisis dengan teknik analisis deskriptif. Hasil penelitian dan pembahasan menunjukan adanya pengembangan kecerdasan interpersonal dan intrapersonal. Maka dapat disimpulkan bahwa kurikulum TK berbasis DAP dapat menstimuli perkembangan kecerdasan interpersonal dan kecerdasan intrapersonal, olehkarena itu guru TK hendaknya dapat memahami kurikulum berbasis DAP dan dapat menerapkannya.
\end{abstract}

Kata Kunci : Kurikulum TK Berbasis DAP, Kecerdasan Interpersonal dan Kecerdasan Intrapersonal.

\section{A. PENDAHULUAN}

Anak usia dini adalah anak yang berusia 0 sampai 6 tahun, sedangkan anak usia sekolah Taman Kanak-Kanak adalah anak berusia 4 tahun sampai 6 tahun, masa ini disebut masa keemasan( golden age), karena peluang perkembangan sangat berharga, semua potensi yag dimilikinya mengalami pertumbuhan dan perkembangan sangat pesat. Bahkan menurut Hurlock (1978) menyatakan bahwa lima tahun pertama kehidupan anak merupakan peletak dasar bagi perkembangan selanjutnya. Untuk memfasilitasinya agar anak-anak usia dini 
dapat berkembang secara optimal maka diamanatkan dalam Undang-Undang RI no 20 tahun 2003 Tentang Sistem Pendidikan Nasional pasal 1 butir 14 dikemukakan bahwa Pendidikan Anak Usia Dini (PAUD) adalah “suatu upaya pembinaan yang ditujukan kepada anak sejak lahir (0 tahun) samapai dengan usia enam(6) tahun yang dilakukan melalui pemberian rangsangan pendidikan untuk membantu pertumbuhan dan perkembangan jasmani dan rohani agar anak memiliki kesiapan dalam memasuki pendidikan lebih lanjut. Sejalan dengan amanat Sisdiknas ini perlu ditunjang dengan kurikulum, yang mana kurikulum ini merupakan salah satu komponen penting dalam proses pendidikan di Taman kanak-Kanak. Sebagaimana dalam Undang-Undang No 20 Tahun 2003 tentang Sistem Pendidikan Nasional dikemukakan bahwa kurikulum adalah seperangkat rencana dan pengaturan mengenai tujuan, isi, dan bahkan pelajaran serta cara yang digunakan sebagai pedoman penyelenggaraan kegiatan pembelajaran untuk mencapai tujuan pendidikan tertentu. Olehkarena itu kurikulum untuk pendidikan anak usia dini perlu dikembangkan secara kreatif. Salah satu alternatif yang memberi banyak peluang untuk mengembangkan secara kreatif, yaitu melalui pengembangan kurikulum berbasis Developmentally Appropiate Practice(DAP), merupakan pendekatan dalam pendidikan yang didasarkan dari hasil penelitian tentang bagaimana anak berkembang dan belajar, dan apa yang diketahui tentang pendidikan dini yang efektif.

Pelaksanaan pendidikan di Taman Kanak-Kanak (TK), peran pendidik sangat strategis terutama dalam upaya pengembangan potensi anak usia 4 - 6 tahun. Upaya pengembangan tersebut harus dilakukan melalui bermain sambil belajar atau belajar seraya bermain. Melalui bermain anak mendapat kesempatan untuk bereksplorasi, berinvestisigasi untuk menemukan dan berkreasi dalam mengekspresikan perasaannya, sehingga mereka mengenal dirinya sendiri, orang lain dan lingkungan dunia sekitarnya. Untuk memfasilitasinya, maka perlu dikembangkan suatu kurikulum yang ideal sesuai dengan kebutuhan perkembangan dan minat setiap anak, serta harus mampu memanfaatkan rasa ingin tahu yang alami ada pada anak untuk mengenal dunia sekitarnya.Merancang kurikulum kreatif menggambarkan adanya perbedaan ide-ide educatif yang 
menstimuli tumbuh kembangnya seluruh potensi perkembangan kecerdasan anak daam hal ini difokuskan pada perkembangan kecerdasan interperonal dan kecerdasan intrapersonal. Pengembangan kurikulum kreatif, pada dasarnya mengacu pada pandangan NAEYC(National Association Of Early Young Childhood) yaitu Developmentally Appropiate Practicec (DAP) atau praktik yang sesuai dengan perkembangan (Wortham, 2006), dan teori kcerdasan majemuk (Multiple intelligence) yang dikembangkan oleh Howard Gardner (1986).

Berdasarkan uraian di atas, maka yang menjadi permasalahan penelitian ini adalah bagaimana model kurikulum berbasis DAP yang secara kondusif mampu menumbuhkembangkan potensi kecerdasan setiap anak TK ? Secara rinci yang menjadi pertanyaan penelitian ini adalah sebagai berikut.

1. Bagaimana model konsep kurikulum PAUD khususnya kelompok usia TK berbasis DAP yang dapat menstimuli perkembangan potensi kecerdasan interpersonal dan intrapersonal

2. Bagaimana model dokumen kurikulum PAUD berbasis DAP khususnya kelompok usia TK yang secara praktis dapat diimplementasikan dalam upaya menstimuli perkembangan potensi kecerdasan interpersonak dan intrapersonal.

3. Bagaimana pedoman implementasi model kurikulum PAUD khususnya kelompok usia TK berbasis DAP yang dapat secara praktis digunakan guru dalam pembelajaran sehingga kondusif untuk menstimuli perkembangan potensi kecerdasan interpersonal dan intrapersonal.

Tujuan Penelitiannya adalah sebagai berikut.

1. Untuk mendapat gambaran konsep kurikulum PAUD khususnya kelompok usia TK berbasis DAP dapat mensimuli perkembangan potensi kecerdasan interpersonal dan intrapersonal

2. Untuk mendapat gambaran model dokumen kurikulum PAUD berbasis DAP khususnya kelompok usia TK yang secara praktis dapat diimplementasikan dalam upaya menstimuli perkembangan potensi kecerdasan interpersonal dan intrapersonal . 
3. Untuk mendapat gambaran pedoman implementasi model kurikulum PAUD khususnya kelompok usia TK berbasis DAP dapat secara praktis digunakan guru dalam pembelajaran sehingga kondusif untuk menstimuli perkembangan potensi kecerdasan interpersonal dan intrapersonal.

\section{B. KAJIAN PUSTAKA}

\section{Konsep Dasar PAUD}

Pendidikan anak usia dini (PAUD) merupakan jenjang pendidikan sebelum memasuki pada jenjang pendidikan dasar. Dalam Undang-Undang no.20 tahun 2003 tentang Sistem Pendidikan Nasional Bab I, Pasal 1 Butir 14 dikemukakan bahwa PAUD merupakan suatu upaya pembinaan yang ditujukan bagi anak sejak lahir sampai usia enam tahun yang dilakukan melalui pemberian rangsangan pendidikan untuk membantu pertumbuhan dan perkembangan jasmani dan rohani agar anak memiliki kesiapan dalam memasuki pendidikan lebih lanjut.

Sementara menurut kajian rumpun keilmuan PAUD di beberapa Negara,PAUD dilaksanakan sejak usia $0 \quad-\quad 8$ tahun yang dalam penyelenggaraannya dapat dilakukan melalui jalur formal, nonformal dan informal. PAUD merupakan salahsatu bentuk penyelenggaraan pendidikan yang menitikberatkan pada upaya pemberian stimulus yang bersifat edukatif agar potensi yang ada pada anak tumbuh dan berkembang secara optimal. Pada dasarnya anak dilahirkan dengan potensi mampu berkembang secara baik, tetapi mereka tidak mungkin melakukan sepenuhnya secara sendiri. Untuk itu anak dalam pengembangan dirinya membutuhkan bantuan yang secara terprogram sesuai dengan kebutuhan perkembangannya. Hal ini sebagaimana dikemukakan Direktorat Pendidikan Anak Usia Dini bahwa pendidikan anak usia dini memiliki fungsi utama mengembangkan semua aspek perkembangan anak. Sehubungan dengan fungsi tersebut maka tujuan pendidikan anak usia diniadalah (1) memberikan pengasuhan dan pembimbingan yang memungkinkan anak usia dinitumbuh dan berkembang sesuai dengan potensinya, (2)mengidentifikasi penyimpangan yang mungkin terjadi sehingga jika terjadi penyimpangan dapat dapat dilakukan intervensi dini, (3)menyediakan pengalaman yang beraneka 
ragam dan mengasikan bagi anak usia dini, yang memungkinkan mereka mengembangkan potensi dalam berbagai bidang, sehingga siap untuk mengikuti pendidikan pada jenjang sekolah dasar(SD). Sejalan dengan paparan di atas dalam PP 17 tahun 2010 tentang Pengelolaan dan Penyelenggaraan Pendidikan dikemukakan bahwa fungsi dan tujuan PAUD diatur dalam pasal 61 yang bunyinya bahwa (1) pendidikan anak usia dini berfungsi membina, menumbuhkan dan mengembangkan seluruh potensi anak usia dini secara optimal sehingga terbentuk perilaku dan kemampuan dasar sesuai dengan tahap perkembangannyaagar memiliki kesiapan untuk memasuki pendidikan selanjutnya,(2)Pendidikan anak usia dini bertujuan (a)membangun landasan bagi perkembangan potensi peserta didik agar memjadi manusia beriman dan bertakwa kepada Tuhan Yang Maha Esa, berakhlak mulia, berkepribadian luhur, sehat jasmani, cakap, kritis, kreatif, inovatif, mandiri, percaya diri dan menjadi warga negara yang demokratis dan bertanggungjawab, dan(b)mengembangkan potensi kecerdasan spiritual, intelektual, emosional, kinestetik dan sosial peserta didik pada masa emas pertumbuhanya dalam lingkungan bermain yang edukatif dan menyenangkan.

\section{Model Kurikulum TK Berbasis DAP}

a. Hakekat DAP

Sejak tahun 1987 National Association Of Early Young Childhood(NAEYC) memberikan laporan tentang Developmentally Appropiate Practice (DAP) untuk anak usia sejak lahir samapi usia 8 tahun. Menurut NAEYC bahwa pendidikan harus sesuai dengan kebutuhan perkembangan anak itu sendiri. Komitmen NAEYC untuk bertindak atas nama anak-anak misinya adalah untuk mempromosikan pendidikan yang berkualitas tinggi. Untuk itu program pendidikan harus dikembangkan sesuai dengan tahap perkembangan anak. Agar program memiliki kontirbusi terhadap perkembangan anak maka harus mengartikaulasikan tujuan untuk perkembangan anak. Prinsip-prinsip dalam praktik yang sesuai dengan perkembangan anak dianjurkan dalam pernyataan selanjutnya tujuan untuk anak-anak di antaranya apa yang kita inginkan dari anak 
-anak dalam mengembangkan kehidupannya sampai dewasa, dan karakteristik pribadi yang bagaimana yang harus dipupuk sehingga kelak mereka dapat berkontribusi untuk masyarakat yang damai, makmur dan demokratis.

Pada dasarnya DAP adalah seperangkat pedoman yang menyarankan konten atau isi kurikulum dan dalam prakteknya memberikan layanan pendidikan sesuai dengan kebutuhan perkembangan setiap anak. Menurut NAEYC (Bredekamp, 1987) bahwa konsep DAP memiliki tiga dimensi yaitu kesesuaian dengan perkembangan usia(age), kesesuaian dengan pertmbuhan individu (individual growth patterns), dan kesesuaian dengan kultur anak(cultural)

b. Konsep Kurikulum TK Berbasis DAP

Kurikulum sebagaimana dikemukakan NAEYC, (1991) Catron dan Allen,(2003) (Divesi, Rose,2008) mendefinisikan kurikulum sebagai “Kerangka kerja yang terorganisir yang menggambarkan konten atau materi pelajaran untuk anak-anak belajar, identifikasi proses berkenaan dengan apa yang harus dilakukan guru untuk membantu anak-anak belajar, dalam mencapai tujuan kurikulum dengan konteks dimana mengajar dan belajar terjadi, lebih jelas Bredekamp \&Rosegrant, (1992) mengemukakan bahwa sebagai kerangka kerja terorganisi.” Mencangkup tiga komponen yaitu; (1)komponen konten meliputi isi atau materi pelajaran, tujuan umum dan tujuan khusus,(2) komponen proses yang menggambarkan pedagogi pelajaran, bagaimana guru mengajar dan cara-cara anak belajar untuk mencapai tujuan umum dan tujuan khusus kurikulum, dan (3)komponen konteks, yang menggambarkan pengaturan (setting) lingkungan belajar yang kondusif bagi anak belajar.

\section{Menumbuhkembangkan Kecerdasan Interpersonal dan Kecerdasan Intrapersonal}

Kecerdasan interpersonal dan kecerdasan intrapersonal merupakan bagian dari kecerdasan majemuk yang diungkapkan oleh Howard Gardner sedangkan psikologi Havard dalam bukunya Frames of Mind (1983, 1993) yang memenangkan, penghargaan berkat pengembangan model kecerdasan majemuk telah memperoleh pengakuan dunia sebagai salah satu teori belajar kecerdasan yang paling inovatif di abad ke 20. Teori kecerdasan majemuk Gardner ini 
memberikan landasan yang kuat untuk mengidentifikasi dan mengembangkan spektrum kemampuan yang luas di dalam diri setiap individu.

Kecerdasan(intelegence) adalah kemampuan untuk memecahkan masalah atau menciptakan suatu produk yang bernilai dalam suatu latarbelakang budaya. Makna kecerdasan menurut Howard Gardner bukan berbicara mengenai seberapa cerdas Anda tetapi bagaimana Anda menjadi cerdas itulah yang lebih penting. Multiple Intellegence (MI)lahir sebagai koreksi terhadap konsep kecerdasan yang dikembangkan oleh Alfred Binet(1904), yang meletakan dasar kecerdasan seseorang pada inteligence Question (IQ) saja. Berdasarkan tes IQ yang dikembangkannya, Binet menempatkan kecerdasan seseorang dalam rentang skala tertentu yang menitikberatkan pada kemampuan berbahasa dan logika semata. Dengan kata lain apabila seseorang pandai dalam logika dan bahasa, maka ia pasti memiliki IQ yang tinggi. Dalam pandangan Gardner bahwa setiap anak mempunyai potensi dengan kadar kecerdasan yang berbeda. Olehkarenanya ke khasan bakat kompetensi seseorang tidak dapat diukur dengan hanya satu aspek maupun satu parameter yang sama. Bagi Gardner tidak ada anak yang bodoh atau pintar, yang ada adalah anak yang menonjol dalah salah satu atau beberapa jenis kecerdasan. Dengan demikian dalam menilai menstimulasi kecerdasan anak, guru selayaknya dengan jeli dan cermat merancang sebuah metode khusus.

Kecerdasan majemuk (multiple intelligence) adalah berbagai jenis kecedasan yang dapat dikembangkan pada anak, antara lain verbal lingistik(kamampuan menguraikan pikiran dalam kalimat-kalimat, presentasi, pidato, diskusi, tulisan), logika matemtika(kemampuan menggunakan logika matematika dalam memecahkan berbagai masalah), Visual spatial(kemampuan berpikir dimensi), bodi kinestetis(keterampilan gerak,menari,olahraga), musikal(kepekaan dan kemampuan berekspresi dengan bunyi dan nada, melodi, irama),intrapersonal(kemampuan memahami dan mengendalikan diri sendiri),interpersonal(kemampuan memahami dan menyesuaikan diri dengan orang lain),naturalis(kemampuan memahami dan memanfaatkan lingkungan). Dalam penelitian ini difokuskan pada pengembangan kecerdasan interpersonal 
dan intrapersonal, untuklebih jelasnya krakteristik kecerdasan tersebut adalah sebagai berikut.

a. Kecerdasan Intrapersonal (Self Smart)

Kecerdasan intrapersonal adalah kemampuan untuk berpikir secara reflektif, yaitu mengacu kepada kecerdasan reflektif mengenai perasaan dan proses pemikiran diri sendiri. Kegiatan ini mencangkup berpikir, meditasi, bermimpi, berdiam diri, mencanangkan tujuan, refleksi, merenung, membuat jurnal, menilai diri waktu menyendiri, proyek yang dirintis sendiri menulis,introspeksi. Materi program kurikulum yang dapat mengembangkan kecerdasan intrapersonal ini antara lain : refleksi, perasaan, self analisis, keyakinan diri, mengagumi diri sendiri, organisasi waktu, perencanaan untuk masa depan, adapun cara yang dilakukan untuk mengembangkan kecerdasan intrapersonal pada anak di antaranya melalui kegiatan menciptakan citra diri positif, menciptakan suasana sekolah yang mengandung pengambangan kemampuan intrapersonal dan penghargaan diri.

b. Kecerdasan Interpersonal(People Smart)

Kecerdasan Interpersonal adalah kemampuan berpikir lewat berkomunikasi dengan orang lain. Ini mengacu kepada keterampilan manusia seperti dapat mudah membaca, berkomunikasi, dan berinteraksi dengan orang lain. Adapun kegiatan yang mencangkup kecerdasan ini adalah meminpin, mengorganisasi, berinteraksi, berbagi, menyayangi, sosialisasi, menjadi pendamai, permainan kelompok, klub, teman-teman kelompok, dan kerjasama. Materi program kurikulum yang dapat mengembangkan kecerdasan ini antara lain ; belajar keompok, mencapai konsensus, tanggungjawab, bermain dalam kehidupan sosial atau pengenalan jiwa seseorang.

\section{METODE PENELITIAN}

Metode penelitian yang digunakan adalah dengan uji coba terbatas dilakukan pada lingkup sampel guru yang terbatas sesuai dengan sampel penelitian ini. Fokus kajian valdasi terbatas lebih diarahkan pada keterbacaan draf naskah akademik, draf dokumen kurikulum kreatif PAUD berbasis DAP, juga 
difokuskan pada ketepatan rumusasn, ruang lingkup dan pengorganisasian isi naskah dokumen kurikulum dan pedoman. Hasil dari validasi terbatas ini dijadikan masukan untuk melakukan refleksi dan hasilnya dilakukan revisi sehingga menghasilkan model dokumen PAUD berbasis DAP yang menumbuhkembangkan kecerdasan interpersonal dan kecedasan intrapersonal anak usia TK dan pedoman implementasinya. Uji validasi lebih luas, dilakukan terhadap sample yang lebih luas, yang meliputi kelas eksperimen dan kelas kontrol.

Penentuan lokasi penelitian atas dasar pertimbangan waktu dan jarak tempuh juga pertimbangan efesien dan efektivitasnya maka pelaksanaan uji validasi lebih luas dilakukan di TK yang ada di kabupaten Bandung. Tepatnya dipilih beberapa TK yang dianggap refresentatif. Aspek yang dikaji pada uji validasi pada dasarnya sama dengan pada uji validasi terbatas, dengan tujuan untuk memperoleh masukan yang lebih lengkap. Perbedaannya pada tahap uji validasi lebih luas dilakukan ekspeimen model dan dibandingkan dengan kelompok kontrol. Selain itu uji validasi lebih luas ini dilakukan pula dengan menggunakan metode Delphi dalam hal ini melibatkan ahli PAUD. Dengan demikian maka produk yang dihasilkan adalah model dokumen kurikulum PAUD berbasis DAP yang mampu menumbuhkembangkan kecerdasan interpersonal dan kecerdasan intra personal anak TK, naskah akademik berupa hand book, dan pedoman implementasinya, baik dalam merencanakan pembelajaran, melaksanakan pembelajaran dan penilaiannya.

TK yang dijadikan sampel penelitian dengan menggunakan purposive sampling, dengan alasan untuk lebih efesien dan efektivitas kegiatan penelitian. TK yang menjadi lokasi penelitian ini adalah TK yang berada di Kabupaten Bandung, tepatnya TK yang berada di wilayah kampus, yakni TK UPI Kampus Cibiru kelompok B, TK Pembina kelompok B1 dan B2, TK Mekar Arum keompok B1 dan B2, serta TK Bhayangkari kelompok B1 dan B2. Sedangkan teknik pengumpulan data dan analisa data yang digunakan dalam penelitian ini adalah angket, wawancara, studi dokumentasi, eksperimen dan observasi. Berdasarkan teknik pengumpulan data tersebut, dapat diperoleh data kualitatif dan 
data kuantitatif. Data kualitatif dianalisis dengan menggunakan teknik analisis deskriptif yang dilakukan secara berkelanjutan sesuai data yang diperoleh, yang meliputi redusi data, penyajian data, simpulan dan verifikasi, adapun data kuantitatif dianalisis dengan menggunakan analisis uji t dan anova yang dalam proses pengolahannya menggunakan bantuan komputer dengan bantuan program komputer dengan program SPSS.

\section{HASIL PENELITIAN DAN PEMBAHASAN}

\section{Proses Uji Coba Model Konsep Kurikulum Berbasis DAP}

a. Proses Uji Coba Model

1) Kegiatan prapembelajaran (seting kelas)

Guru menciptakan kelas menjadi beberapa area, pada setiap area disiapkan berbagai bahan /alat untuk menstimuli anak bermain di area tersebut, setting kelas untuk setiap harinya berbeda-beda sesuai dengan tema dan topik yang dikaji pada hari itu.

2) Kegiatan pendahuluan

Kegiatan ini meliputi berdoa bersama sebelum belajar, dilanjutkan dengan pemberian salam, informasi seputar tema yang akan dikaji dan kegiatan bermain apa yang sudah dipersiapkan oleh guru, dikondisikan untuk kegiatan kelompok berkenaan dengan apa yang akan dilakukan oleh anak seputar tema, seperti tema “Padi” kegiatan pendahuluan dilakukan secara klasikal bentuk lingkaran, lalu guru mengajak untuk berdoa, kemudian menyampaikan salam, dilanjutkan pemberian informasi tentang tema atau topik yang hari itu akan diperkenalkan kepada anakanak, juga informasi tujuan yang diharapkan dapat dicapai anak-anak dan kegiatan yang akan dilakukan oleh anak-anak akan diajak bermain mainan padi, bermain membuat model pa tani dengan kertas warna atau dengan membuat model pa tani cara mozaik. Kegiatan pendahuluan selain dilakukan secara klasikal baik dalam bentuk lingkaran maupun berbaris guru juga mengkondisikan anak dalam kegiatan-kegiatan kelompok. Pada tahap ini guru merancang tugas-tugas yang tepat dilakukan oleh kelompok. Seperti melalui tema "Padi”kegiatan kelompok sangat bervariatif. Di antaranya yaitu anak berkelompok untuk memilih biit padi 
yang baik dan yang kurang baik, anak berkelompok untuk membuat permainan padi dengan media yang sudah disiapkan untuk masing-masing kelompok, anak berkelompok untuk menanambibit padi dalam pot, anak berkelompok untuk merawat tanaman padi, dan kegiatan kelompok lainnya. Kegiatan berbagi dilakukan pada kegiatan pendahuluan, kegiatan ini pada umumnya menindak lanjuti hasil kegiatan kelompok, maksudnya setiap kelompok melaporkan hasil kegiatan kelompoknya baik dalam bentuk produk, maupun secara lisan yang dikondisikan oleh guru dalam kegiatan bercakap-cakap. Seperti pada kegiatan tema "Padi” dengan topik bagian-bagian pohon padi, anak-anak diajak bercakapcakap tentang akar, batang, daun, dan biji padi. Pada topik bibit padi, setelah anak dalam kelompok memilih bibit padi melalui kegiatan percoabaan bibit padi yang terapung dan tenggelam, anak-anak melaporkan bibit padi yang baik adalah yang terapung dan anak mengenal yang terapung lebuh sedikit dari pada yang tenggelam.

3) Kegiatan Inti(Choice Time)

Guru mengajak anak-anak memilih are yang telah disiapkan pada pra kegiatan. Pada saat memilih area bermain guru memberikan keleluasaan, setiap anak memilih area bermain yang paling disukainya terlebih dahulu, lalu mencari area bermain yang lainnya. Pada umumnya anak-anak serius berada disetiap area dan tampak sangatmenyukai dan bahagia. Mereka juga tampak optimal dalam mengekspresikan dirinya, dimana pada area bermain menuntut anak untuk menghasilkan suatu produk. Area yang dikembangkan dalam penelitian ini pada umumnya berbasis proyek, maksudnya anak bermain dalam suatu area diharapkan dapat menghasilkan suatu produk. Seperti pada area musik (membuat ) guru menyediakan beberapa biji-biji an (biji padi, biji kacang merah, jagung,kacang hijau), dan menyediakan kaleng bekas, toples plastik produk-produknya nyaring atau tidaknya musik dari biji-bijian tersebut. Pada area kecerdasan fisik (bermain mozaik) guru menyediakan macam-macam biji beras (merah, putih dan hitam) dan menyediakan kertas manila, lem untuk menempelkan biji-biji beras tersebut. Produknya adalah mozaik bentuk pa tani dari biji beras, pada area natural (menanam padi) guru menyediakan biji padi, tanah lembang, baki dari plastik, dan 
singkup kecil, produk dari area ini anak-anak dalam kelompok dapat membuat persemaian padi dan produk ini perlu ditindaklanjuti seperti setiap hari perlu disiramsehingga biji padinya tumbuh. Temuan dari setiap area yang dikembangkan oleh guru pada umumnya dipilih oleh anak-anak. Uniknya setiap anak berbeda pilihan dan urutan dalam memilih area yang ada setiap anak tampak berusaha untuk dapat menyelesaikan produk yang ada dalam suatu area, agar dapat memilih area yang lainnya.Dalam bermain disuatu area pilihannya ada anak yang secara mandiri bermain tanpa meminta bimbingan guru, tetapi ada anak yang memerlukan bimbingan. Dalam hal ini guru selalu siap untuk membantu jika ada anak yang mendapat kesulitan. Bahkan ada pula Area beermain yang memerlukan kerja tim, seperti area logika matematika (bermain ular tanggayang dikreasikan guru dengan menggunakan model pa tani untuk setiap loncatan permainnannya), tampak anak tertib saling berbagi giliran untuk melempar dadu, bahkan mereka bermain bersama guru. Pada saat anak asyik berada dalam area bermain sesuai pilihannya, guru mengamati mereka dan mencatat perkembangan kecerdasan interpersonal dan intrapersonal maasing-masing anak dalam lembar pengamatan yang telah disediakan.

4) Kegiatan Istirahat

Dilakukan untuk memberikan wktu pada anak membuka bekal yang sudah disiapkan dari rumah masing-masing. Kegiatan ini dimanfaatkan untuk membina kebiasaan yang baik pada saat makan. Anak dibiasakan mencuci tangan, berdoa sebelum makan, dan tertib saat makan, bahkan anak-anak dibiasakan saling berbagi manakala ada anak yang tidak membawa bekal. Kegiatan selanjutnya anak-anak diberi kesempatan untuk bermain di luar kelas, seperti bermain ayunan, prosotan, jungkit-jungkitan atau bermain bak pasir. Pada saat kegiatan bermain tentu guru mengamati aktivitas anak-anak dan mencatat perkembangan potensi kecerdasan interpersonal dan kecerdasan intrapersonal, seperti pada saat bermain dibola dunia anak naik bola dunia dari sebelah kanan kemudian ada juga temannya naik bola duniadari sebelah kiri, lalu mereka bertemu di puncaknya yang sama-sama mereka ingin turun kesebrangnya, pada saat itulah akan terlihat mana anak yang mengalah dan mana anak yang bersikeras memaksa untuk tetap 
turun kesebrangnya, dalam hal ini kecerdasan interpersonal anak mendapatkan tantangan untuk tetap memaksakannya atau mengalah demi memberikan kesempatan pada temannya. Hal tersebut tentunya menjadi catatan bagi guru.

\section{5) Kegiatan Penutup}

Kegiatan akhir ini guru meminta anak-anak menunjukan hasil karya masing-masing yang sudah disimpan ditempat yang sudah disediakan. Seperti anak memghasilkan gambar mozaik model pa tani, oleh guru anak tersebut diminta menceritakan maksud dari gambar mozaik tersebut. Kegiatan ini dapat mengundang semua anak untuk mempublikasikan hasil kerjanya atau juga kesan yang mereka dapatkan saat bermain selain semua anak diberi kesempatan untuk meginformasikan hasil kerjanya, guru menghargai anak yang mempunya prestasi yang luar biasa, salah satu caranya guru mengumumkan karya terbaik dari anak yang prestasinya luar biasa tersebut. Kondisi di atas digunakan oleh guru sebagai kegiatan evaluasi. Dalam hal ini evaluasi dilakukan terhadap hasil karya anak atau yang disebut penilaian produk, selain itu guru juga dapat menilai perkembangan kecerdasan interpersonal pada saat menunjukan hasil karyanya dapat dilihat rasa percaya dirinya atau konsep dirinya.

\section{b. Hasil Uji Coba Kurikulum Berbasis DAP}

Uji coba model kurikulum berbasis DAP difokuskan pada upaya untuk menstimuli perkembangan kecerdasan interpersonal dan kecerdasan intrapersonal merupakan bagian dari kecerdasan majemuk yang merupakan hasil penelitian Howard Gardner. Dari uji coba model yang dilakukan sebanyak tiga kali di TK Laboratorium UPI Kampus Cibiru, perolehan perkembanganpotensi kecerdasan diklasifikasikan dengan menggunakan skala $1-4$ dengan makna 1 belum berkembang, 2 berarti mulai berkembang, 3 berarti berkembang sesuai harapan, 4 berarti berkembang sangat baik. Dari jumlah anak 11 orang berarti skor ideal maksimalnya 44 , berdasarkan hasil penilaian terhadap setiap anak diperoleh sejumlah skor yang kemudian dipadankan dengan klasifikasi penskoran. Kecerdasan interpersonal pada petemuan ke 1 mencapai skor 14 berarti pada umumnya mulaiberkembang, pertemuan ke 2 mencapai skor 24 berarti pada umumnya berkembang sesuai haapan, dan ke 3 mencapai skor 34 berarti pada 
umumnya berkembang sangat baik. Kecerdasan intrapersonal pertemuan ke 1 mencapai skor 13 pada umumnya belum berkembang, pertemuan ke 2 mencapai skor 24 pada umumnya berkembang sesuai harapan, pertemuan ke 3 mencapai skor 34 berarti pada umumnya berkembang sangat baik.

\section{Hasil Validasi Model Kurikulum Berbasis DAP}

Validasi model kurikulum di tiga TK yaitu TK Pembina, TK Mekar Arum, dan TK Bhayangkari. Setiap TK memiliki kelas B dua kelas, yaitu B1 dan B2. Dengan demikian ke dua kelas tersebut ditetapkan kelas B1 sebagai kelas eksperimen dan kelas B2 sebagai kelas kontrol, adapun hasil uji coba dari masingmasing TK digambarkan sebagai berikut.

a. TK Pembina

Uji validasi yang dilakukan di TK Pembina dari tiga kali pertemuan, jumlah anak 18 orang anak dengan perhitungan skor 1-18 belum berkembang, 19 - 36 mulai berkembang, 37 - 54 berkembang sesuai harapan, 55 - 72 berkembang sangat baik.

Kecerdasan Interpersonal pada pertemuan ke 1 mencapai skor 30 berarti pada umumnya mulai berkembang, pertemuan ke 2 mencapai skor 45 berarti pada umumnya berkembang sesuai harapan, pertemuan ke 3 mencapai skor 54 berarti pada umumnya berkembang sanhat baik. Kecerdasan Intrapersonal, pertemuan ke1 mencapai skor 28 pada umumnya mulai berkembang, perteman ke 2 mencapai skor 44 pada umumnya berkembang sesuai harapan, dan pertemuan ke 3 mencapai skor 54 berarti pada umumnya berkembang sesuai harapan pula.

b. TK Mekar Arum

Keseluruhan setiap kecerdasan anak 16 orang anak dengan perhitungan skor 1 - 16 belum berkembang, 17 - 32 mulai berkembang, 33- 48 berkembang sesuai harapan, 49 - 64 berkembang sangat baik. Kecerdasan Interpersonal pada pertemuan ke 1 mencapai skor 21 berarti pada umumnya mulai berkembang, pertemuan ke2 mencapai skor 43 berarti berkembang sesuai harapan, pertemuan ke 3 mencapai skor 59 berarti pada umumnya berkembang sangat baik. Kecerdasan Intrapersonal, pertemuan ke 1 mencapai skor 21 pada umumnya mulai 
berkembang, pertemuan ke2 mencapai skor 43 berkembang sesuai harapan, dan pertemuan ke3 mencapai skor 56 pada umumnya berkembang sangat baik.

c. TK Bhayangkari

Hasil uji validasi pelaksanaan model kurikulum berbasis DAP di TK Bhayangkari kelas eksperimen menggambarkan perkembangan kecerdasan interpersonal dan intrapersonal. Hal ini ditandai dengan jumlah 12 orang anak dengan perhitungan skor 1- 12 belum berkembang, 13 - 24mulai berkembang, 25 - 36 berkembang sesuai harapan, 37 - 48 berkembang sangat baik. Kecedasan interpersonal, pada pertemuan ke 1 mencapai skor 18 berati pada umumnya mulai berkembang, pertemuan ke 2 mencapai skor 33 berarti berkembang sesuai harapan, dan pertemuan ke 3 mencapai skor 38 berarti pada umumnya berkembang sangat baik. Kecerdasan Intrapersonal, pertemuan ke 1 mencapai skor 22 pada umumnya mulai berkembang, pertemuan ke2 mencapai skor 38 dan pertemun ke 3 mencapai skor 39 pada umumnya berkembang sangat baik.

\section{Pembahasan}

Hasil penelitian berdasarkan kajian teoritik dan pengalaman di lapangan pengembangan model kurikulum DAP, mendapatkan suatu gambaran bahwa model kurikulum TK berbasis DAP adalah sebagai kerangka kerja yang terorganisir, mencangkup tiga komponen utama yaitu (1).komponen tujuan dan isi, (2).komponen proses menggambarkan pendekatan pedagogi, bagaimana guru menciptakan pelajaran bagi anak usia dini, untuk mencapai tujuan dan (3).komponen konteks, yang menggambarkan pengaturan(setting) lingkungan belajar yang kondusif bagi anak belajar.

a. Model Dokumen Kurikulum TK Berbasis DAP

Menyusun model dokumen TK berbasis DAP dari hasil kajian teoritik dan pengalaman di lapangan, pada dasarnya tidak ada dokumen yang dibakukan, dengan alasan pada (1) pemahaman tentang bagaimana anak berkembang dan belajar, sehingga program lebih berpusat pada anak, (2). Mengutamakan pentingnya setting lingkungan dalam bentuk area yang kaya dengan berbagai bahan dan alat -alat permainan yang dapat menjadi pilihan bagi anak untuk 
bermain seraya belajar, (3). Penilaian merupakan bagian integral pelaksanaan pembelajaran.

b. Pedoman Implementasi Model Kurikulum TK Berbasis DAP

Mengacu pada berbagai sumber tentang pengembangan DAP terutama dari NAEYC pada penelitian ini difokuskan terutama pada empat hal, yaitu berkaitan dengan, (a) program, (b) strategi pembelajaran, (c)lingkungan belajar, dan (d) penilaian.

Berdasarkan temuan penelitian bahwa potensi kecerdasan interpersonal dan intrapersonal yang dimiliki anak dapat berkembang secara optimal, jika guru secara sengaja menciptakan pembelajaran yang diarahkan untuk menstimuli perkembangan potensi kecerdasan tersebut.

\section{E. KESIMPULAN DAN SARAN}

Model kurikulum berbasis DAP dapat menstimuli perkembangan potensi kecerdasan interpersonal dan kecerdasan intrapersonal, srta pada dasarnya merupakan kerangka kerja yang terorganisir mencangkup tiga komponen yakni,(1) tujuan dan isi kurikulum, (2).komponen proses yang mengambarkan pendekatan pedagogi, dan (3). Komponen konteks yang menggambar kan pengaturan lingkungan belajar yang kondusif. Model dokumen kurikulum berbasis DAP mengacu pada pengemabangan kurikulum terpadu yang mengemas berbagai konten ke dalam satu unit tematik yang secara kreatif disesuaikan dengan kebutuhan perkembangan usia. Pengemabangan model kurikulum TK berbasis DAP ini sangat kondusif dalam menumbuhkembangkan potensi kecerdasn interpersonal dan intrapersonal anak, oleh karena itu para guru TK sebaiknya memahami dengan baik konsep kurikulum berbasis DAP ini dan menghayatinya, kemudian dapat secara bertahap menerapkannya.

\section{DAFTAR PUSTAKA}

Amstrong, Thomas(2002).Setiap Anak Cerdas Panduan Membantu Anak Belajar Dengan Memanfaatkan Multiple Intelligencenya. Jakarta: Gramedia Pustaka Utama 
Bredekamp, S.And C.Copple(eds).(1997).Developmentally Appropriate PracticeinEarly ChildHood Program(rev. Ed).Washington, DC : National Assosiation for the Education of Young Children

Carol Gestwicki.(2008).Developmentally Appropiate Practice : Curriculumand DevelopmentIn Early Education. Canada : Thomson Delmar Learning

Child Departement Center(tanpa tahun)DevelopmentallyAppropiatePractice (on line)http//www.tr,wou.edu/train/ededap.htm

Departemen Pendidikan Nasional. (2004) Kurikulum Berbasis Kompetensi Taman Kanak-Kanak. Jakarta: Balitbang Depdiknas.

Departemen Pendidikan Nasional (2007).Kurikulum Pendidikan Taman KanakKanak dan Pedoman Penyusunan Silabus. Jakarta : BP. Cipta Jaya

Direktorat Pendidikan Anak Usia Dini(2011)Fungsi dan tujuan Direktorat Pendidikan Anak Usia Dini (on line)

Gardner, Howard (2002).Mutiple Intelligence - Kecerdasan Majemuk Teori dan PraktekJakarta : Interaksara

Megawangi, R. dkk.(2005).Pendidikan yang Patut dan Menyenangkan : Penerapan Teori Developmentally AppropiatePractice(DAP). Depok : Indonesia Heritage Faundation

Nugraha,Ali dkk.(2005).Kurikulum dan Bahan Belajar TK. Jakarta : Universitas Terbuka 